\title{
Corporate Governance Mechanisms and Real Earnings Management: Evidence from Indonesia
}

\author{
Maria Goreti Kentris Indarti ${ }^{1}$, Faisal Faisal ${ }^{2}$, Etna Nur Afri Yuyetta ${ }^{3}$, Jacobus Widiatmoko ${ }^{4}$ \\ \{kentris@edu.unisbank.ac.id ${ }^{1}$, fe faisal@yahoo.co.id ${ }^{2}$,etna.yuyetta@gmail.com ${ }^{3}$, jwidiatmoko@edu.unisbank.ac.id $\left.{ }^{4}\right\}$ \\ ${ }^{1,4}$ Faculty of Economics and Business Universitas Stikubank Semarang, Jalan Kendeng V Bendan Ngisor Semarang, \\ ${ }^{2,3}$ Faculty of Economics and Business Universitas Diponegoro, Tembalang Semarang 50275
}

\begin{abstract}
This paper discusses how the corporate governance mechanism determines the opportunistic behavior of management in the form of earnings management practices with real activities manipulation. This study provides benefits to the development of literature by examining the effect of corporate governance mechanisms on real earnings management practices in the manufacturing sector listed on the Indonesia Stock Exchange (IDX) 2016-2018. Using purposive sampling method, 224 data were obtained. Multiple regression analysis use to test hypothesis, and the results showed that the existence of independent commissioner is able to reduce the level of real earnings management. Instead, the existence of audit committee cannot reduce the opportunistic behavior of management. This finding proved the need to strengthen the mechanism of corporate governance through the existence of independent commissioners. Regarding the ownership structure, this study was unable to prove the role of share ownership by institutions and management in reducing real earnings management practices.
\end{abstract}

Keywords: Corporate governance mechanism, real earnings management, Indonesia Stock Exchange

\section{Introduction}

Earnings is the important information used by shareholders in making investment decisions and is a criterion in evaluating the performance of managers, as well as a basis for determining the compensation to be paid [1], [2]. Therefore, managers have an incentive to manage earnings by using various means and maneuvers that can deceive investors about the strength of the firm's earnings [1], [3], [4].

Earnings management is seen as a fundamental reason for widespread financial scandals, which cause great concern for the quality of financial information [5]. Earnings management can be classified into two categories, namely accrual earnings management (AEM) and real earnings management (REM) [6], [7]. AEM is done by changing the accounting method to increase the earnings base, which will be returned in future periods, so that it has no impact on the company's cash flow. REM is the result of deviations from the norms of normal business practices, including loose sales credit policies, reducing discretionary costs, or overproduction to achieve revenue targets [6], [8]. REM is more dangerous for companies because it will have a direct impact on business decisions and cash flow. Previous research has shown that REM lowers future operating performance and firm value [9], [10].

Agency theory is a theoretical body that studies the contractual relationship between management and principals. The two related parties have their respective interests, giving rise to agency problems [11]. Earnings management is one such agency problem. The difference in interests between agents and principals can be resolved with a mechanism, namely good corporate governance so that management as an agent acts by prioritizing the interests of shareholders [12]. Corporate governance is a system that ensures that the company is well managed by management, which prioritizes the interests of stakeholders. Therefore, the quality of corporate governance mechanisms largely determines how management will behave opportunistically [13].

The quality of corporate governance can be evaluated based on the principles of disclosure and transparency, relationships with shareholders and stakeholders, characteristics of commissioners, policies and compliance, as well as ownership and supervision structures [14], [15]. The importance of corporate governance mechanisms in minimizing opportunistic actions of management such as earnings management practices has encouraged researchers to examine the relationship between corporate governance mechanisms and REM.

This study examines the influence of corporate governance mechanisms through ownership structures and board features. This research is motivated by several reasons which are at the same time a contribution of this research. First, research on the relationship between company ownership structure and the size of REM is still very limited and does not necessarily focus on ownership concentration and managerial ownership. Previous research has been conducted to look at the relationship between ownership structure and AEM [10], [16]. 
However, considering the more dangerous long-term effects because REM can reduce cash flow and firm value, real earnings management needs more attention from researchers [2], [17], [18].

Second, an empirical study of earnings management shows that managers switch from AEM techniques to REM techniques and are widely used in developed countries to increase reported earnings. The phenomenon in China also shows that the shift in accounting standards from principle to rule base has caused a shift in earnings manipulation from AEM to REM [3], [19]. This is done because AEM is easily detected by auditors and supervisory mechanisms, so the costs are greater than the benefits. This research contributes theoretically and empirically by filling in existing research gaps. Since 2012 Indonesia has implemented a full adoption of IFRS, making it possible shift in earnings management practices to REM. Therefore, this research is important because the REM effect is more dangerous than AEM, namely the decrease in cash flow and company value. The composition of this paper consists of introductory section, theoretical review and hypothesis development, the research methods used in this study, findings and empirical explanations, conclusions, and the limitations of this research and suggestions for further research.

\section{Literature Review}

Real earnings management (REM), or manipulation of real activities is an act of deviation from the norms of normal business practices undertaken by management, including a loose sales credit policy, reducing discretionary costs, or overproduction to achieve profit targets [8], [20]. There are three reasons why managers prefer to manipulate with real activities [21]: 1) unlike AEM which is within the scope of the audit, REM is more likely to be undetected by auditors and regulators 2) REM can be done throughout the year, whereas accrual earnings management only occurs at the end of the quarter or fiscal year. Management that has no earnings target will be sufficient and risky only by accrual manipulation, so that the need to perform REM effectively, 3) companies that use AEM in previous years will appear on the balance sheet, so managers tend to do REM in this period when they are motivated to manipulate continuous earnings.

The relationship between corporate governance and REM can be explained by agency theory. The direct impact of agency problems between management and shareholders is the emergence of earnings management practices. This conflict of interest requires a mechanism or system of corporate governance that can encourage management to behave in the best interests of shareholders over their own interests. Consequently management opportunistic behavior will depend on how efficient and effective the corporate governance mechanism is. The better the quality of governance, the lower the management's incentives to opportunistically manage earnings [13].

Institutional investors are long-term oriented investors. Compared to other owners, institutional investors are more active in monitoring management. They are also more sophisticated in using financial information for decision making [2]. Based on an efficient monitoring hypothesis, the negative relationship between institutional share ownership and the level of corporate earnings management can be maintained and has been empirically confirmed [16]. [22] proved that if the number of shares owned by the institution is getting bigger, then they will be tighter in monitoring so that REM actions by management can be suppressed. The findings of [2] proved that institutional shareholders in Latin American companies play an important role in preventing REM practices by management. Based on the description above, the following hypothesis is proposed:

H1: Institutional ownership has a negative effect on real earnings management

Agency theory predicts a difference in interests between management as the party mandated to manage the company and shareholders, especially those from outside the company [11]. Managerial ownership that is increasingly high can align the interests of shareholders with management and reduce agency costs, thereby increasing the value of the company. Based on the logic of this thought, [23] stated as a hypothesis of alignment of interests. Management as an insider tries to align their interests with those of shareholders. Managerial ownership can improve contract protection and job security of CEOs and help reduce earnings management practices [24]. The greater the number of shares owned by management, the greater the management's intention to align their interests with shareholders, thereby reducing the tendency to carry out REM [2]. [10] found evidence of the effects of managerial ownership alignment with REM mitigation on companies in China. Based on the logic of thought and empirical support above, the following hypothesis was formulated.

$\mathrm{H} 2$ : Managerial ownership has a negative effect on real earnings management

The board of commissioners has an important role in protecting the interests of shareholders. This role is manifested in the form of supervision of management in managing the company. The agency approach shows that the existence of an independent commissioner in the board of commissioner structure is a key feature of an effective corporate governance framework [25] and can reduce agency costs arising from the separation of ownership and control. Independent commissioners can carry out monitoring effectively [26], [27], thereby increasing earnings quality by reducing opportunities for earnings management and fraud actions by people in the company [28]. 
[29] found that the existence of independent commissioners in companies in the UK was able to suppress earnings management levels with real activities. Independent commissioners exert a far greater influence on demand for high-quality financial information and reduce management's intention to manage earnings. [13] proved that the independent commissioner was able to carry out effective monitoring of management, so as to suppress earnings management actions. Based on these findings, the researcher suspected that the existence of an independent commissioner resulted in an effective monitoring function and could reduce real earnings management practices, so the hypothesis was formulated as following.

H3: Independent commissioners negatively affect real earnings management

An audit committee is a committee formed by and is responsible to the board of commissioners in helping carry out the duties and functions of the board of commissioners. An increasing number of audit committees tend to have members with diverse expertise to monitor financial reporting practices more effective [30]. Research by [13] proved that the audit committee performs the supervisory function effectively, thereby reducing the opportunistic behavior of management in the form of earnings management. Based on these findings, the researchers suspect that the greater the number of committee members the higher their knowledge of real earnings management and how to detect it. Therefore, the hypothesis is stated as follows.

H4: The audit committee has a negative effect on real earnings management

\section{Methodology and Data Analysis}

The population in this study is manufacturing companies listed on the Indonesia Stock Exchange in 20162018. The sample was selected using the purposive sampling method and produced samples in each year in a row 68,81 and 75 , so the amount of data in this study was 224 .

The operational definitions and measurements of each variable are explained below. Real earnings management variables are measured by a model developed by [8]. Several researchers have previously used the formula and proved that the proxy can capture real earnings management behavior accurately [6], [31], REM measurement is divided into three, namely; abnormal operating cash flow, abnormal production costs, and abnormal discretionary costs, as follows. The normal operating cash flow is estimated using the following model:

$$
\mathrm{CFO} \text { t/At }-1=\alpha 0+\alpha 1(1 / \text { At }-1)+\beta 1(\mathrm{St} / \mathrm{At}-1)+\beta 2(\Delta \mathrm{St} / \mathrm{At}-1)+\varepsilon \mathrm{t}
$$

Where:

$\mathrm{CFO} \mathrm{t}=$ cash flow from operating activities at the end of period $\mathrm{t}$

At-1 = the total assets at the end of period $\mathrm{t}-1$

St $\quad=$ the sales during period $\mathrm{t}$

$\Delta \mathrm{St} \quad=\mathrm{St}-\mathrm{St}-1$

The normal production costs are estimated using the following regression formula:

$$
\text { PROD t/At- } 1=\alpha 0+\alpha 1(1 / \text { At- } 1)+\beta 1(\text { St } / \text { At }-1)+\beta 2(\Delta \text { St } / \text { At }-1)+\beta 3(\Delta \text { St-1/At- })+\varepsilon t
$$

Where:

PROD $\mathrm{t}=$ the cost of goods sold (COGS) in year $\mathrm{t}$ and the inventory change from $\mathrm{t}-1$ to $\mathrm{t}$

At-1 = the total assets in year $\mathrm{t}-1$

$\mathrm{St} \quad=$ the net sales in year $\mathrm{t}$ and

$\Delta \mathrm{St} \quad=$ the change of net sales from year $\mathrm{t}-1$ to $\mathrm{t}$.

Then, abnormal discretionary expenditure is estimated by the following cross-section regression.

$$
\text { DISEXP t/At- } 1=\alpha 0+\alpha 1(1 / \text { At- } 1)+\beta(\text { St-1/At- } 1)+\varepsilon t
$$

Where:

DISEXP $\mathrm{t}=$ the discretionary expenses i.e., the amount of research $\&$ development $(\mathrm{R} \& \mathrm{D})$, advertising and sales, general \& administrative (SG\&A expenses) in year $\mathrm{t}$.

At-1 = the total assets in year $\mathrm{t}-1$.

St-1 = the net sales in year $\mathrm{t}-1$.

The coefficients obtained in each model are normal operating cash flow values, production costs, and discretionary costs reduced by normal values to get abnormal values from each measurement used as a proxy for real earnings 
management. Then all three values are added together to get management values real earnings. The equation for real earnings management is as follows:

$$
\mathrm{REM}=(\mathrm{ACFO} *-1)+\mathrm{APROD}+(\mathrm{ADISEXP} *-1)
$$

Where:

REM = real earnings management.

ACFO $\quad=$ Abnormal cash flow from operation.

APROD $\quad=$ Abnormal production cost.

ADISEXP $\quad=$ Abnormal discretionary expenses.

Institutional ownership is the ratio between the number of shares owned by institutional investors and the total shares of a company [2], Managerial ownership is the ratio between the number of shares owned by the manager and the number of shares outstanding [16], Independent commissioners are measured using a proportion of the number of independent board of commissioners to the total board of commissioners [30], and the audit committee is measured by the number of audit committee members [30]. Leverage, profitability and size as control variables in this study, each measured using a ratio between total debt to total assets, ratio between net income to total assets and $\log$ natural assets [32], [33].

The data analysis technique used in this study is ordinary least square regression with the following equation.

$$
\mathrm{REM}=\alpha+\beta 1 \mathrm{INST}+\beta 2 \mathrm{MAN}+\beta 3 \mathrm{IND}+\beta 4 \mathrm{AUDIT}+\beta 5 \mathrm{LEV}+\beta 6 \mathrm{PROF}+\beta 7 \mathrm{SIZE}+\varepsilon
$$

\begin{tabular}{|c|c|}
\hline Where: & \\
\hline REM & $=$ Real earnings management \\
\hline INST & $=$ Institutional ownership \\
\hline MAN & $=$ Managerial ownership \\
\hline IND & $=$ Independent Commissioner \\
\hline AUDIT & $=$ Audit Committee \\
\hline LEV & $=$ Leverage \\
\hline PROF & $=$ Profitability \\
\hline SIZE & $=$ Firm size \\
\hline$\varepsilon$ & $=$ Error term \\
\hline
\end{tabular}

\section{Research Result and Discussion}

The results of residual normality testing in the first stage showed the value of skewness and kurtosis respectively of 29.626 and 108.525 . This value is greater than 1.96 , so the residuals in the regression model are not normally distributed. The next step is to transform data by eliminating outlier data and retesting. The results of the second stage of the test showed a skewness value of 0.155 , smaller than 1.96 and a kurtosis value of -1.876 , greater than -1.96 , so that the residual distribution in the regression model is normally distributed.

The value of durbin watson in the autocorrelation test shows the number 1.967. This number is between the du value of 1.8312 and the 4-du value of 2.1688, which means that in the regression model there is no autocorrelation problem. Table 1 show that all independent variables have significance values above alpha 5\%, so that in the research model there are no heteroscedasticity problems. Information in Table 2 shows that all independent variables have tolerance values above 0.10 and the value of the variance inflation factor (VIF) is less than 10, so the regression model is free from multicollinearity problems.

\begin{tabular}{|c|c|c|c|c|c|}
\hline \multirow[t]{2}{*}{ Model } & \multicolumn{2}{|c|}{$\begin{array}{c}\text { Unstandardized } \\
\text { Coefficients }\end{array}$} & \multirow{2}{*}{$\begin{array}{c}\begin{array}{c}\text { Standardized } \\
\text { Coefficients }\end{array} \\
\text { Beta }\end{array}$} & \multirow[t]{2}{*}{$\mathrm{t}$} & \multirow[t]{2}{*}{ Sig } \\
\hline & B & Std. Error & & & \\
\hline (Constant) & -3.378 & 4.195 & & -.805 & .422 \\
\hline INST & .398 & .896 & .050 & .444 & .658 \\
\hline MAN & .971 & 1.186 & .097 & .818 & .414 \\
\hline IND & .606 & 1.836 & .029 & .330 & .742 \\
\hline AUDIT & .170 & .607 & .024 & .280 & .780 \\
\hline LEV & .531 & .310 & .146 & 1.716 & .088 \\
\hline PROF & 1.769 & 2.576 & .061 & .687 & .493 \\
\hline SIZE & -.079 & .119 & -.063 & -.666 & .507 \\
\hline
\end{tabular}

Table 1. Heteroscedasticity Testing Results, Dependent variable: Abres 
The OLS regression test results in Table 2 show a calculated F statistics of 12.419 with a significance level of 0.000 , which means the model built in this study is fit and can be used to predict the dependent variable, namely real earning management. The adjusted $\mathrm{R}^{2}$ value shows the number 0.352 , which means that $35.20 \%$ variation in REM can be explained by the independent variables in this research model, the remaining 64.80 is explained by other variables not included in the research model.

Table 2. Regression Testing Results, Dependent variable: REM, ***) sig. at alpha 5\%

\begin{tabular}{|c|c|c|c|c|c|c|c|}
\hline \multirow[b]{2}{*}{ Model } & \multicolumn{2}{|c|}{$\begin{array}{c}\text { Unstandardized } \\
\text { Coefficients }\end{array}$} & \multirow{2}{*}{$\begin{array}{c}\begin{array}{c}\text { Standardized } \\
\text { Coefficients }\end{array} \\
\text { Beta }\end{array}$} & \multirow[b]{2}{*}{$\mathrm{t}$} & \multirow[b]{2}{*}{ Sig } & \multirow[b]{2}{*}{ Tolerance } & \multirow[b]{2}{*}{ VIF } \\
\hline & $\mathrm{B}$ & Std. Error & & & & & \\
\hline (Constant) & 3.028 & .426 & & 7.105 & .000 & & \\
\hline INST & .034 & .098 & .031 & .345 & .730 & .551 & 1.816 \\
\hline MAN & -.160 & .130 & -.117 & -1.235 & .219 & .495 & 2.020 \\
\hline IND & -.423 & .176 & -.162 & -2.397 & $.018 * * *$ & .960 & 1.042 \\
\hline AUDIT & -.073 & .067 & -.074 & -1.090 & .278 & .963 & 1.039 \\
\hline LEV & .232 & .034 & .467 & 6.842 & $.000 * * *$ & .946 & 1.057 \\
\hline PROF & 1.041 & .280 & .262 & 3.714 & $.000 * * *$ & .885 & 1.130 \\
\hline SIZE & -.072 & .013 & -.420 & -5.563 & $.000 * * *$ & .773 & 1.294 \\
\hline \multicolumn{2}{|c|}{ Adjusted R Square } & $: \quad .352$ & & & & & \\
\hline \multicolumn{2}{|l|}{ F Statistics } & : 12.419 & & & & & \\
\hline \multicolumn{2}{|l|}{ Sig. } & $: \quad .000$ & & & & & \\
\hline
\end{tabular}

As shown in Table 2, the beta coefficient value on the variable institutional ownership is 0.034 with a significance level of 0.730 . These results indicate that institutional ownership has no effect on real earnings management, so the first hypothesis is rejected. Managerial ownership has a beta coefficient of -0.160 with a significance level of 0.495 , so the second hypothesis is rejected. Beta coefficient on the independent commissioner variable shows the number -0.423 with a significance level of 0.018 , so the third hypothesis is accepted. The audit committee variable shows a beta coefficient of -0.073 with a significance level of 0.278 . These results indicate that the audit committee has no effect on real earnings management, so the fourth hypothesis is rejected. The results of testing of the three control variables indicate that leverage and size have an influence on real earnings management in the predicted direction. Conversely, profitability has a positive effect on real earnings management but the direction of the relationship is not as predicted.

The results of testing the first hypothesis indicate that institutional ownership does not affect REM. This result does not support the agency theory which states that the existence of institutional investors serves as a monitoring mechanism for management actions. This result is also not in line with [2], [22] research, which proves that institutional ownership can reduce REM. Managerial ownership does not affect REM. This result is not in line with agency theory which states that increasingly high managerial ownership can align interests between shareholders and management. This result also does not support previous research conducted by [2], [10]. As hypothesized, independent commissioners influence REM. The results of this study support the findings of previous researchers namely [13], [19], which proves that independent commissioners negatively influence REM practices. This finding shows that the independent commissioner is able to carry out the oversight and monitoring functions of management, so that the opportunistic behavior of management in the form of REM can be reduced. The audit committee in this study was also not proven to have an effect on REM actions by management. The results of this study do not support agency theory which explains that the audit committee is tasked with assisting and strengthening the function of the board of commissioners in carrying out the oversight function of the financial reporting process, risk management, audit implementation, and implementation of corporate governance in the company. These findings reinforce the notion that the existence of the audit committee merely fulfills the regulations of the Financial Services Authority (OJK) [34].

\section{Conclusion}

This study examines the effect of corporate governance structure, which consists of institutional ownership, managerial ownership, independent commissioners and audit committees on real earnings management in manufacturing companies listed on the Indonesia Stock Exchange. The results showed that the independent commissioner variable had a negative effect on real earnings management. Independent commissioners are able to carry out their functions effectively in ensuring adequate control over management. The three corporate 
governance structure variables, namely institutional ownership, managerial ownership, and audit committee have no effect on earnings management practices with the real activities carried out by management. The test results on the control variables show that leverage and size affect the real earnings management. Meanwhile, the profitability variable has the opposite effect from the predicted direction.

\section{Implications/limitations and suggestions for further research}

Apart from the contributions that can be made, this study has several limitations that require improvement and development in further research. These limitations include the relatively low adjusted $\mathrm{R}^{2}$ value of 0.352 or 35,2. In addition, of the four corporate governance structure variables, only the independent commissioner variable is proven to have a negative effect on real earnings management. The researcher then needs to consider the proxy of external corporate governance mechanisms such as audit quality or corporate governance perception index (CGPI), measurement of corporate governance mechanisms whose calculations have considered various aspects of commitment, transparency, accountability, responsibility, independence, fairness, compensation, leadership, ability to work together, the realization of vision, mission, and corporate governance, moral ethics, and strategy.

\section{References}

[1] P. Dechow, W. Ge, and C. Schrand, "Understanding earnings quality: A review of the proxies, their determinants and their consequences," J. Account. Econ., vol. 50, no. 2-3, pp. 344-401, 2010, doi: 10.1016/j.jacceco.2010.09.001.

[2] C. Mellado and P. Saona, "Real earnings management and corporate governance: a study of Latin America," Econ. Res. Istraz., vol. 33, no. 1, pp. 2229-2268, 2020, doi: 10.1080/1331677X.2019.1691930.

[3] M. Shayan-Nia, P. Sinnadurai, Z. Mohd-Sanusi, and A. Ni. A. Hermawan, "How efficient ownership structure monitors income manipulation? Evidence of real earnings management among Malaysian firms," Res. Int. Bus. Financ., vol. 41, pp. 54-66, 2017, doi: 10.1016/j.ribaf.2017.04.013.

[4] Y. Zhang, J. Perols, D. Robinson, and T. Smith, "Earnings management strategies to maintain a string of meeting or beating analyst expectations," Adv. Account., vol. 43, no. September, pp. 46-55, 2018, doi: 10.1016/j.adiac.2018.09.001.

[5] M. El Diri, "Definitions, activities, and measurement of earnings management," in Introduction to earnings management, Springer, 2018, pp. 5-44.

[6] A. Y. Zang, "Evidence on the trade-off between real activities manipulation and accrual-based earnings management," Account. Rev., vol. 87, no. 2, pp. 675-703, 2012, doi: 10.2308/accr-10196.

[7] L. C. J. Ho, Q. Liao, and M. Taylor, "Real and accrual-based earnings management in the pre- and postIFRS periods: Evidence from China,” J. Int. Financ. Manag. Account., vol. 26, no. 3, pp. 294-335, 2015 , doi: $10.1111 /$ jifm. 12030 .

[8] S. Roychowdhury, "Earnings management through real activities manipulation," J. Account. Econ., vol. 42, no. 3, pp. 335-370, 2006, doi: 10.1016/j.jacceco.2006.01.002.

[9] D. A. Cohen and P. Zarowin, "Accrual-based and real earnings management activities around seasoned equity offerings," J. Account. Econ., vol. 50, no. 1, pp. 2-19, 2010, doi: 10.1016/j.jacceco.2010.01.002.

[10] N. Dong, F. Wang, J. Zhang, and J. Zhou, "Ownership structure and real earnings management: Evidence from China," J. Account. Public Policy, vol. 39, no. 3, p. 106733, 2020, doi: 10.1016/j.jaccpubpol.2020.106733.

[11] M. C. Jensen and W. H. Meckling, "Theory of the Firm: Managerial," J. financ. econ., vol. 3, pp. 305-360, 1976, doi: http://dx.doi.org/10.1016/0304-405X(76)90026-X.

[12] S. Claessens and B. B. Yurtoglu, "Corporate Governance in Emerging Markets: A Survey," SSRN Electron. J., pp. 1-77, 2012, doi: 10.2139/ssrn.1988880.

[13] P. Saona, L. Muro, and M. Alvarado, "How do the ownership structure and board of directors' features impact earnings management? The Spanish case," J. Int. Financ. Manag. Account., vol. 31, no. 1, pp. 98133, 2020, doi: 10.1111/jifm.12114.

[14] R. Luqman, M. Ul hassan, S. Tabasum, M. S. Khakwani, and S. Irshad, "Probability of financial distress and proposed adoption of corporate governance structures: Evidence from Pakistan," Cogent Bus. Manag., vol. 5, no. 1, pp. 1-14, 2018, doi: 10.1080/23311975.2018.1492869.

[15] T. M. Shahwan, "Crisis de la conciencia nacional en torno al 98," Hist. la nación y del Nac. español, vol. 15 , no. 5, pp. 543-562, 2015. 
[16] A. Piosik and E. Genge, “The influence of a company's ownership structure on upward real earnings management," Sustain., vol. 12, no. 1, pp. 1-24, 2020, doi: 10.3390/SU12010152.

[17] P. M. Dechow, R. G. Sloan, and A. P. Sweeney, "Causes and consequences of earnings manipulation: An analysis of firms subject to enforcement actions by the SEC," Contemp. Account. Res., vol. 13, no. 1, pp. 1-36, 1996, doi: 10.1111/j.1911-3846.1996.tb00489.x.

[18] M. Walker, "How far can we trust earnings numbers? What research tells us about earnings management," Account. Bus. Res., vol. 43, no. 4, pp. 445-481, 2013, doi: 10.1080/00014788.2013.785823.

[19] D. A. Cohen, A. Dey, and T. Z. Lys, "Real and Accrual-Based Earnings Management in the Pre- and PostSarbanes-Oxley Periods," vol. 83, no. 3, pp. 757-787, 2008, doi: 10.2308/accr.2008.83.3.757.

[20] D. A. Cohen, S. Pandit, C. E. Wasley, and T. Zach, "Measuring Real Activity Management," Contemp. Account. Res., vol. 37, no. 2, pp. 1172-1198, 2020, doi: doi:10.1111/1911-3846.12553.

[21] M. Alhadab and I. Clacher, "The impact of audit quality on real and accrual earnings management around IPOs," Br. Account. Rev., vol. 50, no. 4, pp. 442-461, 2018, doi: 10.1016/j.bar.2017.12.003.

[22] J. Goh, H. Y. Lee, and J. W. Lee, "Majority Shareholder Ownership and Real Earnings Management: Evidence from Korea," J. Int. Financ. Manag. Account., vol. 24, no. 1, pp. 26-61, 2013, doi: 10.1111/jifm. 12006.

[23] M. Bennedsen and K. M. Nielsen, "Incentive and entrenchment effects in European ownership," J. Bank. Financ., vol. 34, no. 9, pp. 2212-2229, 2010, doi: 10.1016/j.jbankfin.2010.02.007.

[24] X. Chen, Q. Cheng, A. K. Lo, and X. Wang, "CEO contractual protection and managerial short-termism," Account. Rev., vol. 90, no. 5, pp. 1871-1906, 2015, doi: 10.2308/accr-51033.

[25] R. Dixon, G. A. Mousa, and A. Woodhead, "The role of environmental initiatives in encouraging companies to engage in environmental reporting," Eur. Manag. J., vol. 23, no. 6, pp. 702-716, 2005, doi: 10.1016/j.emj.2005.10.014.

[26] S. Alves, "The effect of board independence on the earnings quality: Evidence from portuguese listed companies," Australas. Accounting, Bus. Financ. J., vol. 8, no. 3, pp. 23-44, 2014, doi: 10.14453/aabfj.v8i3.3.

[27] J. P. Swai and C. S. Mbogela, "Accrual-based versus real earnings management; the effect of ownership structure: Evidence from East Africa," ACRN Oxford J. Financ. Risk Perspect., vol. 5, no. 2, pp. 121-140, 2016, [Online]. Available: http://www.acrn-journals.eu/resources/jofrp0502h.pdf.

[28] P. Wasan and K. Mulchandani, "Corporate governance factors as predictors of earnings management," $J$. Gen. Manag., vol. 45, no. 2, pp. 71-92, 2020, doi: 10.1177/0306307019872304.

[29] B. G. Osma, "Board independence and real earnings management: The case of R\&D expenditure," Corp. Gov. An Int. Rev., vol. 16, no. 2, pp. 116-131, 2008, doi: 10.1111/j.1467-8683.2008.00672.x.

[30] J. Sun, G. Lan, and G. Liu, "Independent audit committee characteristics and real earnings management," Manag. Audit. J., vol. 29, no. 2, pp. 153-172, 2014, doi: 10.1108/MAJ-05-2013-0865.

[31] A. S. Wibowo and F. Fuad, "Growth Illusion in The Indonesia Stock Exchange: Relationship Between Earnings Management and Firm Value,” Indones. J. Account. Res., vol. 21, no. 1, pp. 75-100, 2018, doi: 10.33312/ijar.336.

[32] J. Widiatmoko and M. G. K. Indarti, "Book Tax Differences, Operating Cash Flow, Leverage and Earning Persistence in Indonesia Manufacturing Companies," J. Account. Dyn., vol. 11, no. 2, pp. 151-159, 2019, doi: 10.15294/jda.v11i2.20481.

[33] J. Widiatmoko, M. G. K. Indarti, and I. D. Pamungkas, "Corporate governance on intellectual capital disclosure and market capitalization," Cogent Bus. Manag., vol. 7, no. 1, pp. 1-14, 2020, doi: 10.1080/23311975.2020.1750332.

[34] Y. K. Susanto and A. Pradipta, "Corporate governance and real earnings management," Int. J. Business, Econ. Law, vol. 9, no. 1, pp. 17-23, 2016, doi: 10.24297/jssr.v5i2.3378. 